\title{
Synthesis of PLGA nanoparticles of tea polyphenols and their strong in vivo protective effect against chemically induced DNA damage [Erratum]
}

Srivastava $\mathrm{AK}$, Bhatnagar $\mathrm{P}$, Singh $\mathrm{M}$, et al. Int $J$ Nanomedicine. 2013;8:1451-1462.

Upon reviewing the article, the authors noticed the PCR gel images were difficult to view in Figures 6
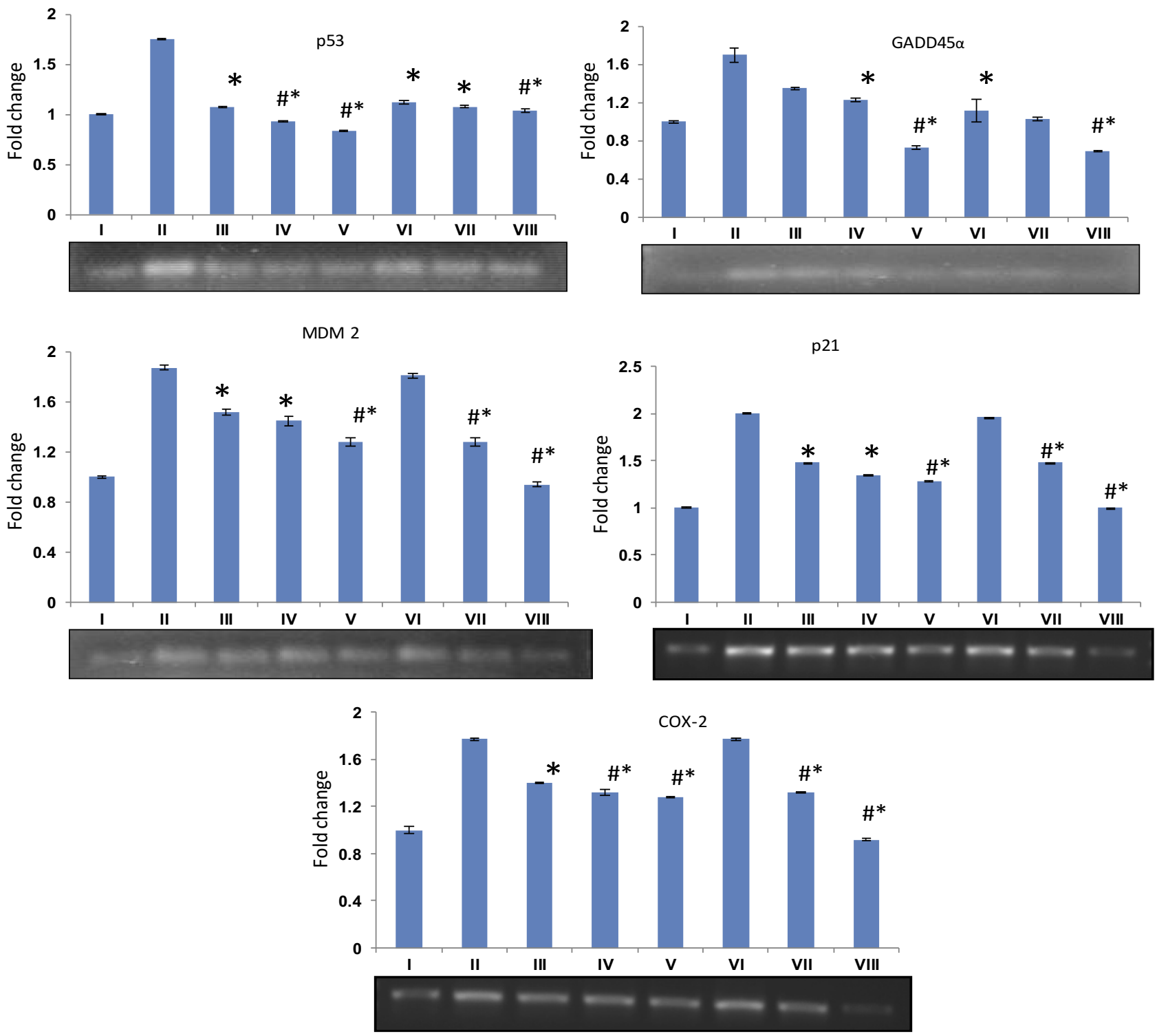

Figure 6 Effect of bulk and PLGA-loaded tea polyphenols on the transcription of DNA damage responsive genes. The pixel density of the specific mRNA expression bands was quantified by densitometry and expressed as a fold difference against $\boldsymbol{\beta}$-actin.

Notes: Data shown is the result of three different experiments with similar results. The data were significant at $* P<0.05$ in comparison to Group II; \#indicates significant effect of nanotized

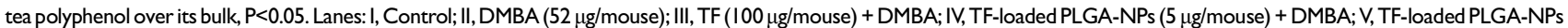

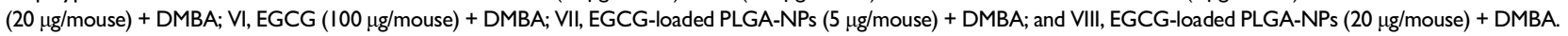

Abbreviations: DMBA, 7,I2-dimethylbenzanthracene; EGCG, epigallocatechin-3-gallate; NP, nanoparticle; PLGA, poly(lactide-co-glycolide); TF, theaflavin. 

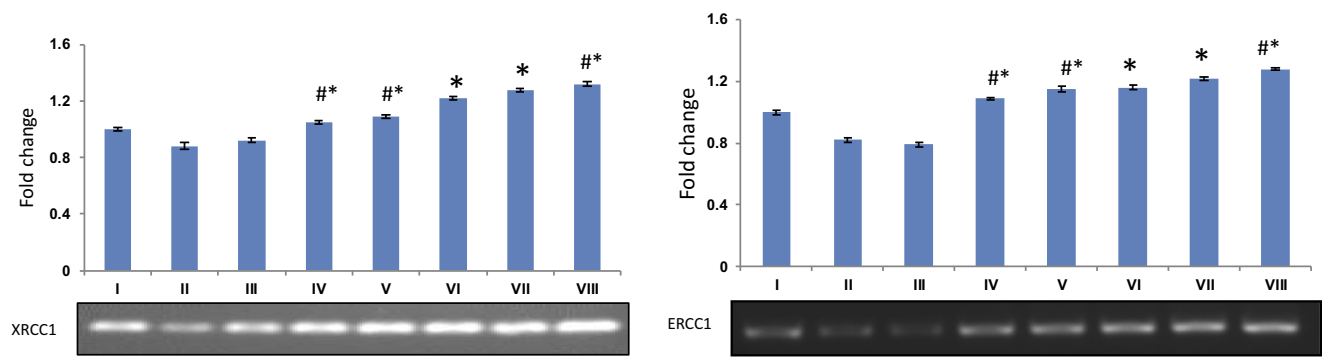

XRCC1

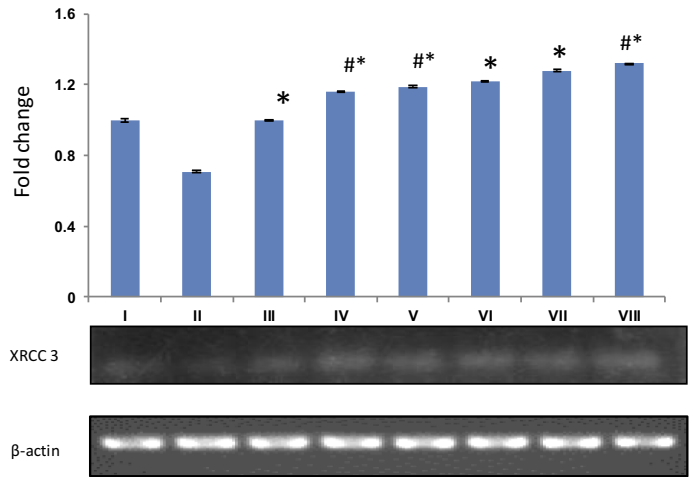

Figure 7 Effect of bulk and PLGA-loaded tea polyphenols on the transcription of DNA repair responsive genes. The pixel density of the specific mRNA expression bands was quantified by densitometry and expressed as a fold difference against $\boldsymbol{\beta}$-actin.

Notes: Data shown is the result of three different experiments with similar results; the data were significant at $* P<0.05$ in comparison with Group II; \#indicates significant effect of nanotized tea polyphenol over its bulk, P<0.05. Lanes: I, Control; II, DMBA (52 $\mu \mathrm{g} / \mathrm{mouse})$; III, TF (I00 $\mu \mathrm{g} / \mathrm{mouse})+\mathrm{DMBA}$; IV, TF-loaded PLGA-NPs (5 $\mu \mathrm{g} /$

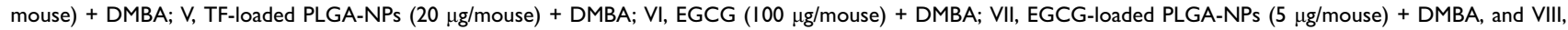
EGCG-loaded PLGA-NPs $(20 \mu \mathrm{g} /$ mouse $)+$ DMBA.

Abbreviations: DMBA, 7,I2-dimethylbenzanthracene; EGCG, epigallocatechin-3-gallate; NP, nanoparticle; PLGA, poly(lactide-co-glycolide); TF, theaflavin

\section{Publish your work in this journal}

The International Journal of Nanomedicine is an international, peerreviewed journal focusing on the application of nanotechnology in diagnostics, therapeutics, and drug delivery systems throughout the biomedical field. This journal is indexed on PubMed Central, MedLine, CAS, SciSearch ${ }^{\circledR}$, Current Contents ${ }^{\circledR} /$ Clinical Medicine,
Journal Citation Reports/Science Edition, EMBase, Scopus and the Elsevier Bibliographic databases. The manuscript management system is completely online and includes a very quick and fair peer-review system, which is all easy to use. Visit http://www.dovepress.com/ testimonials.php to read real quotes from published authors. 